\title{
The Vocational Education Thinking of Diverse Artistic Talents Cultivation in the Context of New Media
}

\author{
Xudong $\operatorname{Jin}^{1, \text { a }}$ \\ ${ }^{1}$ Nanjing Institute of Railway Technology, Nanjing, Jiangsu, China, 210031 \\ ${ }^{\mathrm{a}}$ email
}

Keywords: New Media Context, Art Colleges, Artistic Talents Cultivation, Advantage, Challenge

\begin{abstract}
Art Colleges with the aid of the great advantages of modern technology of new media development, in time to change the traditional art of personnel training strategy and the diversified artistic talents foster vocational education thinking. This paper first explores the status of development of new media and then analyzes the institutions of higher learning in the context of new media personnel training strengths and challenges, and then provides recommendations for the new media context of various art forms of vocational education personnel training new thinking.
\end{abstract}

\section{Introduction}

With modern technology, the development of the Internet, the media has undergone significant changes. Modern networks, digital television, digital radio, digital audio and video, blog, podcasts, micro-channel and other new media develop into an explosive situation. Emergence of new media on traditional media is a great shock to the audience offers a richer, more convenient way to get media resources. Especially with the development of mobile media, portable media communication is becoming more and more common way of contemporary young people access to information. These developments indicate that we have entered a new era of media. Modern Art Colleges in nurturing artistic talent should also make full use of the powerful benefits of the new media, innovative thinking their vocational education in the new media context, foster more pluralistic artistic talents. In the context of new media filled every corner of our lives down, if you ignore the importance of the new media context, modern art institutions cannot produce more to meet the social development needs of the times of high-quality artistic talents.

\section{The Advantages of New Media Context in the Arts Colleges Talent Training}

Emergence of new media a short time, but the development speed very quickly, to podcasts, for example, since 2007, the earliest Chinese personal blog, and today the country has hundreds of millions of people have their own blog, the timely transmission of information by ordinary citizens blog conduct online communication with other people. China has entered the era of new media context. Art colleges in personnel training has begun to realize the great advantage of the new media, we are gradually changing the concept of the past, personnel training and methods. Cultivating summary of new media in the context of art school talent advantages, mainly in the following points:

The New Media Context Provides More Resources for the Art Talent Training. Emergence of new media for institutions of higher art cultivate of artistic talents to provide a more convenient platform for artistic resource acquisition. Obtaining traditional art resources mainly through the art of paper-related materials, access arts education resources are very inconvenient. Therefore, the new media context largely subverted the way to get the art of teaching resources. Art teachers can convenient new media platforms, such as network resources platform to obtain teaching resources they need. By helping the relevant search engines, filter your unwanted content, quickly find timely collection of educational resources they need. With the new media, it can store and share resources powerful tools, such as cloud networking, sharing and storage resources. The help of this platform, we can also conduct online interaction between different schools and absorb each other learn the advantages of both sides. In short, new media art context diversified training provides more colorful 
art resources. Get advantage of this powerful resource is the traditional media cannot match.

The New Media Context Provides More Open Learning Environment for the Art Talent Training. Traditional art teaching environment mainly in the fixed art teachers, art teaching requires a lot of specialized equipment. The new media has changed the context of the traditional teaching environment, art teachers can spread by means of new media tools, such as mobile phones and other media, the creation of virtual teaching environment. This teaching environment has changed in the past fixity of traditional teaching and learning environment, and more flexible. As the art of teaching content uploaded to the virtual classroom, allowing students to advance research teaching in a virtual learning environment, then learning appears difficult problems presented to the network platform, through online interactive way to communicate, ask someone for help. This will greatly improve the efficiency of teaching, teachers in the classroom as long as the focus on the difficult problems that exist in learning to prepare class design and teaching. Setting the context of new media and open teaching environment and it is the trend of the future of art school education reform. Western countries have begun to explore the art teaching and practice of such problems, there has been present in the education sector increasingly popular "flipped classroom" teaching form. This gives our universities arts education provides a new reference and ideas. By the Context of the new media to create a new open learning environment is an effective way to foster future art diverse artistic talents.

New Media Context Improve the Efficiency to Cultivate Artistic Talents. Under the new media context, art school students learn positive change occurs quietly. More students choose by means of new media in the arts courses and exchange activities. If students learn timely information through mobile media arts school curriculum and effective course preview. Convenient means of mobile media networking, students can timely access to knowledge and information they need to form an initial understanding of the course content. In the classroom, as long as the focus on solving difficult problems in their own rehearsal is not understood we can successfully complete the program of study. Under the new media context, students learn to become more proactive, learning efficiency will get an unprecedented increase. New Media Context to provide more online communication platform for university teaching to cultivate artistic talents. With the new media powerful resource sharing and other advantages can be obtained in a timely manner of communication between students learning, sublimate their own understanding of textbook knowledge. In short, the new media context will not only help teachers of institutions of higher art education work more smoothly carried out, but also greatly improve the efficiency of student learning.

\section{The Challenge of Arts Colleges Talent Training in the New Media Context}

While the talent of new media in the context of art institutions to cultivate a distinct advantage, however, Talent Education College Art New Media Context also faces enormous challenges.

Have a Bad Impact on the Traditional Art Personnel Training Mode. Traditional art talent cultivation mode is primarily through classroom-based teachers. However, with so many students inside the classroom, art teachers in the actual teaching process can not cover everything. At the same time, this passive cramming teaching process, but also reduces the initiative of student learning. Emergence of new media is a great impact on the traditional art of personnel training mode. Students through new media context, in time get a lot of arts education resources they need. It has begun satisfied with the traditional textbook knowledge classroom teachers taught. They often make some more profound artistic issues that no ready answers in the textbook. No wonder some students of art teachers reflect modern thinking very active, very specific questions raised, cannot own a reasonable solution. Lag of the impact of new media on traditional art context personnel training mode produced this art education in the future of arts education in Art Colleges will become more prominent.

Propose Higher Innovation Requirements for the Traditional Art Teaching Content. Under the new media context, rich in arts education resources, access to resources and efficient manner, the ability to interact online with powerful advantages, to provide a new convenient teaching 
resources, but also the traditional art of teaching content put forward higher requirements for innovation. However, in the current art teaching curriculum of the traditional arts of teaching the content is still the mainstream and limiting the diffusion of artistic thinking of students. Teaching content and some art colleges, such as art education theory used for many years, too old to meet the needs of the modern art of teaching. Adverse consequences, the teachers on the dull, and even the burnout of the teaching work. This affects largely the work of art teaching institutions of higher art, to be timely if not innovative teaching content, the longer the worse the effect will be teaching. This is an important issue cannot be ignored in our institutions of higher art education in the arts, facing.

Propose Higher Teaching Skills Requirements for Art Teachers. Development of modern society needs more high-quality multi artistic talents. However, in the new media environment, arts teacher existing teaching and teaching thinking skills has been unable to meet the needs of the art of teaching. Traditional art education, such as art education, as long as doing art foundation to explain the relevant knowledge on the line, a classroom, a blackboard, a few enough to support the needs of art education. Therefore, many arts teachers have formed fixity of art teaching thinking, teaching skills increasingly rigid. They treat new media context of teaching methods, although has also changed. But the problem is limited to the objective reality of the new media technologies using insufficient teaching thinking change slowly and it is to enhance teaching skills shortage. Accustomed to traditional teaching methods, teachers and even some of the new art of teaching methods under the new media context of psychological conflict. As the use of computer network to find relevant arts education resources, some art teachers might as well do the students in place. The development of modern art education, art education has given our institutions of higher learning and higher requirements. If engaged in arts education teachers thinking is so conservative and traditional teaching methods, or so, will not be able to meet the needs of future development of innovative arts education.

\section{The Recommendations of the Formation of Vocational Education New Thinking of Multiple Arts Personnel Training in the New Media Context}

Establish a New Multi Arts Talents Training Policy in New Media Context. The new media may provide context for the establishment of this model. With the new media, strong advantages in resources, institutions of higher art can effectively change the past, training model. As the above are talking about the context of new media platforms, we can achieve docking with the social market, keep abreast of the latest art market information, the establishment of pluralistic future artistic talent training policy more in line with social development needs. Market-oriented, professional artistic talents pluralistic culture, not only conducive to the Art Students faster and enhance their artistic quality, while the students' future employment and other practical problems also have a positive role in promoting. Higher long-term development of art institutions is also of great significance. In short, China's institutions of higher art to the times, by means of new media context superiority to establish a new multi artistic talent training strategy as soon as possible to train more high-quality professional artistic talents for the country community.

Really Change the Outdated Status of Quo Prior Art Teaching Content. To create a new Multi Media Art Context personnel training mode, but also to change the existing status of the old art of teaching content. Modern Art Colleges teaching of art in order to do the work, we must change the shackles of the traditional teaching of the original content. Of course, the traditional teaching content still has a lot of positive educational significance today. Therefore, we must be cautious traditional art teaching content, to those who still have a positive educational teaching content we have to be retained. The content of teaching retention nor accept it, according to the requirements to be innovative arts education.

Strengthen the Training of Using New Media Arts Technology for Teacher. Art is art teachers teaching the final executor, to improve their training under the context of the new era of new media technology related media use. Specifically, the first to be carried out in the art of the middle of teachers in the new media educational philosophy publicity, so that they change the traditional art education thinking; the second is to hire specialized people for art teachers in the media use of 
technology training to enhance their new media technology proficiency; Third, to form the corresponding evaluation mechanisms, new media use first line of skilled arts teachers to timely recognition and encouragement, and they can pay for performance were linked, if necessary, drive real interests, will lead the art teachers themselves seek change. Through these concrete measures, it can effectively enhance the artistic skills of teachers in the use of new media and new media context by means of realization of their art teaching paradigm shift. This is not only conducive to the development of art teachers themselves, but also help institutions of higher art Multi Art Talents implement strategy.

Establish a "Flipped Classroom" Teaching Mode. Higher arts education should learn the practice of art institutions in Western countries, the establishment of a "flipped classroom" new mode of teaching. The so-called flipped classroom, is to change the orientation of teaching order, students become the first part of the teacher's teaching to become the second link. With the strong advantage of new media context, before students can conduct their own lessons on the appropriate course content learning. As a convenient means of mobile media networking, students can timely access to knowledge and information they need to form an initial understanding of the course content. Thus in the classroom, as long as the focus on solving difficult problems in their own rehearsal is not understood we can successfully complete the program of study. In this classroom orientation of teachers, knowledge is no longer the traditional art of explaining how, as a student learning assistant, answer difficult questions raised by the students. In the flipped classroom teachers, teaching can save a lot of time to concentrate on teaching the art of research, promote update their teaching philosophy, teaching skills upgrading. In short, this new flipped classroom teaching model has become popular in the United States and Europe, some of our colleges and universities have also been the practice, and achieved positive results. Art Colleges in art teaching should also actively engaged in changing teaching mode, to establish their own school characteristics of the "flipped classroom" teaching model.

\section{Conclusions}

In short, in the new media context, Arts Institutes of China to establish a dedicated multi nurture artistic talent strategy, a more practical vocational education in line with the teaching of thinking. Innovation should actively study new media art teaching context, changing the status quo of existing arts education content lag, the arts teacher use new media technology training, the establishment of belonging to the school characteristics of the "flipped classroom" teaching model. In nurturing artistic talent, as long as attention to this practice, it can promote the development of higher art teaching institutions of the future arts institutions to provide more high-quality artistic talents for the development of the state and society.

\section{References}

[1] Xu Qingxiao: Popular Literature, Vol. 4 (2012) No 53, p.58-62

[2] Gao Xinru: Art Education, Vol. 8 (2014) No 27, p.69-73

[3] Luo Ying, Yu Zhongwen: Art Research, Vol. 4 (2008) No 33, p.11-14

[4] Luo Ying, Yu Zhongwen: Wuhan University Journal (Philosophy and Social Sciences), Vol. 6 (2008) No33, p.121-124

[5] Xu Yun, Kang Jian: Nanjing Normal University (Social Science Edition), Vol. 6 (2011) No33, p.121-124

[6] Wang Ying: Art Education Research, Vol. 11 (2011) No33, p.121-124 